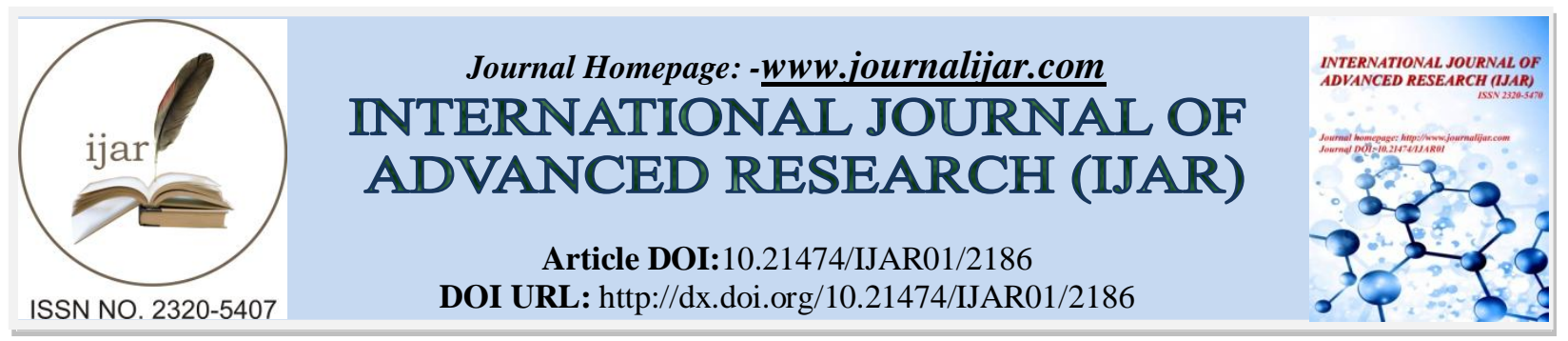

RESEARCH ARTICLE

\title{
COMPARATIVE STUDY OF THE EFFICACY OF COMBINED SOFOSBUVER RIBAVIRIN IN TREATMENT NAIVE VERSUS EXPERIENCED EGYPTIAN PATIENTS WITH CHRONIC HEPATITIS C.
}

Ayman El-Badawy, Mohamed Yehia Seddek, Mohamed Shawky El-sayed and Azez Mohammed Bedeer. Internal medicine department,Faculty of medicine, Banha University, Qalyubia, Egypt.

\section{Manuscript Info}

Manuscript History

Received: 27 September 2016

Final Accepted: 30 October 2016

Published: November 2016

\section{Abstract}

Background \& Aims: We conducted this study to assess the efficacy and safety of the oral nucleotide polymerase inhibitor sofosbuvir in combination with ribavirin in Egyptian patients, chronically infected with genotype 4 hepatitis $\mathrm{C}$ virus (HCV).

Methods:Treatment-naive and previously treated patients with genotype $4 \mathrm{HCV}$ were randomly allocated in a 1:1 ratio to receive sofosbuvir $400 \mathrm{mg}$ and weight-based ribavirin, for 24 weeks. The primary efficacy endpoint was the proportion of patients with sustained virologic response (HCV RNA <25 IU/ml) 12 weeks after cessation of therapy (SVR12).

Results: treatment-naive and previously treated patients were enrolled and treated for 24 weeks SVR12 was achieved by $68 \%$ of patients in the 24-week group. The most common adverse events were headache, insomnia, and fatigue. No patient discontinued treatment due to an adverse event.

Conclusions:The findings from the present study suggest that 24 weeks of sofosbuvir plus ribavirin is an efficacious and well tolerated treatment in patients with HCV genotype 4 infection.

Copy Right, IJAR, 2016,. All rights reserved.

\section{Introduction:-}

The genotype 4 strain of the hepatitis $\mathrm{C}$ virus (HCV) accounts for approximately $20 \%$ of all cases of chronic $\mathrm{HCV}$ infection worldwide) Khattab et al. J Hepatol 2011).

In Egypt, where an estimated $15 \%$ of the population may have chronic hepatitis C, over $90 \%$ of the infections have been reported to be HCV genotype 4 ( Khattab et al., 2011). (Guerra J et al., J Viral Hepat 2012). The spread of chronic HCV infection in Egypt is thought to be largely due to needle re-use during mass-treatment programs for schistosomiasis during the late 1950s through the early 1980s ( Frank C, Khattab MA et al 2000 -rao MR, et al. 2002) [epub]. Unfortunately, transmission continues to occur, primarily through iatrogenic sources, such as blood transfusions, injections, and dental care (Khattab MA et al 2011, Wantuck JM et al 2014). HCV genotype 4 is also the most common genotype in other parts of the Middle East and Africa, and its prevalence is increasing in Europe and parts of North America where it has been associated with immigration and intravenous drug use (Khattab MA et al 2011) Until recently, the standard of care for genotype $4 \mathrm{HCV}$ in the United States and Europe has been pegylated interferon (PegIFNa) with ribavirin (RBV) for 24 to 48 weeks, depending on virologic response (Khattab MA et al 2011). Treatment-naive patients receiving this regimen have sustained virologic response (SVR) 
rates of $43 \%$ to $70 \%$ (Khattab MA et al 2011,Wantuck JM et al 2014,Esmat G et al 2012). New regimens involving direct-acting antiviral agents (DAAs) have recently been approved for the treatment of genotype $4 \mathrm{HCV}$. These regimens appear to offer improved rates of SVR in treatment-naive and previously treated patients with genotype $4 \mathrm{HCV}$. One of the newly approved DAAs indicated for the treatment of genotype $4 \mathrm{HCV}$ is sofosbuvir (Gilead Sciences, Inc., Foster City, California, USA), an oral, HCV-specific NS5B nucleotide polymerase inhibitor with demonstrated clinical efficacy in patients with genotype 1 to 6 HCV (Lawitz E et al 2013, Jacobson IM et al 2013).

The current hepatitis $\mathrm{C}$ treatment guidelines for treatment of genotype $4 \mathrm{HCV}$ issued by the American Association for the Study of Liver Diseases (AASLD), European Association for the Study of the Liver (EASL), and World Health Organization (WHO) include sofosbuvir administered in combination with PegIFNa and RBV for 12 weeks or an interferon-free regimen of sofosbuvir in combination with RBV for 24 weeks (AASLD et al 2014 -EASL ET AL 2014).

The development of an interferon-free regimen for genotype $4 \mathrm{HCV}$ infection has the potential to significantly impact the incidence, prevalence, and overall burden of $\mathrm{HCV}$, particularly in Egypt, where the prevalence of genotype $4 \mathrm{HCV}$ is so high. For many, treatment with interferon-containing regimen is impossible, undesirable, or insufficiently efficacious. Elimination of interferon from the treatment regimen may reduce the required frequency of safety monitoring, and facilitate treatment of chronic hepatitis $\mathrm{C}$ in rural areas, which in Egypt have higher prevalence rates than the national average (Guerra $\mathbf{J}$ et al 2012). We have afforded the opportunity to perform a pilot study of an interferon-free regimen containing sofosbuvir plus RBV for 24 week in treatment-naive and treatment-experienced Egyptian patients with HCV genotype 4 infection.

\section{Material and Methods:- \\ Patients:-}

Patients were screened and enrolled in this studyatshebinelkomeducational hospital at the interferon and treatment of hepatic viruses unit.

Patients were required to be at least 18 years of age with chronic genotype 4 HCVinfection with a serum HCV RNA is positive.

The age of naïve patient ranged from $36-61$ (mean $\pm \mathrm{SD}=46.33 \pm 6.91$ ) while the age of experienced patients ranged from 35-59 (mean $\pm \mathrm{SD}=49.07 \pm 7.01$ ). The majority were males for both groups $80 \%$ and $73.33 \%$.

\section{Study design:-}

Patients were randomly assigned in a 1:1 ratio to receive treatment with sofosbuvirplus RBV for 24 weeks. . Sofosbuvir was given orally at a dose of $400 \mathrm{mg}$ once daily, and weight-based RBV was given orally as a divided weight-based daily dose (1000 mg for patients with body weight $<75 \mathrm{~kg}$ and $1200 \mathrm{mg}$ with body weight P75 mg). RBV dose adjustment was permitted according to prescribing instructions. Use of growth factors was not permitted.

\section{Statistical assessments:-}

The primary efficacy endpoint was the proportion of all randomized patients whoachieved a sustained virologic response 12 weeks after the end of treatment (SVR12).

In the primary efficacy analysis, SVR12 rates were calculated for each treatment group, No statistical hypothesis testing was performed. 


\section{Results:-}

Table 1:-Characteristics of the studied groups.

\begin{tabular}{|c|c|c|c|c|c|}
\hline \multirow[t]{2}{*}{ variables } & \multicolumn{2}{|c|}{$\begin{array}{l}\text { Naïve patients } \\
(n=15)\end{array}$} & \multicolumn{2}{|c|}{$\begin{array}{l}\text { Experienced } \\
(\mathbf{n}=15)\end{array}$} & \multirow{2}{*}{$\begin{array}{l}\text { Significance test } \\
\text { p- value }\end{array}$} \\
\hline & no & $\%$ & No & $\%$ & \\
\hline $\begin{array}{l}\text { Sex: } \\
\text { males } \\
\text { Females }\end{array}$ & $\begin{array}{l}12 \\
3\end{array}$ & $\begin{array}{l}80 \\
20\end{array}$ & $\begin{array}{l}11 \\
4\end{array}$ & $\begin{array}{l}73.33 \\
26.67\end{array}$ & $\begin{array}{l}X^{2}=0.186 \\
P=0.666 \\
\text { NS }\end{array}$ \\
\hline $\begin{array}{l}\text { Age(years): } \\
35- \\
40- \\
50- \\
\text { Range } \\
\text { Mean } \pm \text { SD }\end{array}$ & $\begin{array}{l}3(2 \\
7(4 \\
5(3 \\
36- \\
46 .\end{array}$ & & $\begin{array}{l}1(6 \\
6(4 \\
8(5 \\
35- \\
49 .\end{array}$ & & $\begin{array}{l}\text { t-test }=1.068 \\
p=0.295 \\
\text { NS }\end{array}$ \\
\hline
\end{tabular}

Table (1): shows the characteristics of the studied naïve and experienced patients as regards age and sex. It shows that the age of naïve patient ranged from 36-61

(Mean $\pm \mathrm{SD}=46.33 \pm 6.91$ ) while the age of experienced patients ranged from 35-59

(Mean $\pm \mathrm{SD}=49.07 \pm 7.01$ ) .the majority were males for both groups $80 \%$ and $73.33 \%$

Fig (1): Pie chart for sex frequency of Naïve patients

This chart show that the majority of naïve patients are males which represent $80 \%$ while females represent $20 \%$

\section{Fig (2): Pie chart for sex frequency of experienced patients}

This chart show that the majority of experienced patients are males which represent $73 \%$ while females represent $27 \%$

Fig (3): bar chart for sex distribution of the studied groups

Table2:-Comparison between Naive andexperienced treatmentpatients as regard ALT.

\begin{tabular}{|l|l|l|l|l|}
\hline \multirow{2}{*}{ Variable } & \multicolumn{2}{|l|}{ ALT } & \multicolumn{2}{l|}{ significance-test } \\
\cline { 2 - 5 } & $\begin{array}{l}\text { Naive patients } \\
(\mathrm{n}=15)\end{array}$ & $\begin{array}{l}\text { Experienced patients } \\
(\mathrm{n}=15)\end{array}$ & t-test & $\mathrm{p}$-value \\
\hline range & $22-200$ & $9-121$ & 1.878 & 0.071 \\
\hline Mean \pm SD & $87.8 \pm 53.45$ & $57.867 \pm 30.863$ & & \\
\hline
\end{tabular}

Table (2) shows the comparison between Naïve and experienced patients as regards their mean \pm standard deviation for ALT. it shows that level of ALT ranged 22-200 for Naïve with mean \pm SD equal to 87.8 \pm 53.45 while the level for experienced ones ranged from 9-121 with mean \pm standard deviation equal to $57.87 \pm 30.87$. the difference between both groups was not significant statistically $(\mathrm{p}=0.071)$

\section{Fig(4): Bar chart for Mean \pm SD of ALT of the studied groups}

Table3:-Comparison between Naive andexperienced treatmentpatients as regard AST.

\begin{tabular}{|l|l|l|l|l|}
\hline \multirow{2}{*}{ Variable } & AST & \multicolumn{2}{l|}{ significance-test } \\
\cline { 2 - 5 } & $\begin{array}{l}\text { Naive patients } \\
(\mathrm{n}=15)\end{array}$ & $\begin{array}{l}\text { Experienced patients } \\
(\mathrm{n}=15)\end{array}$ & t-test & $\mathrm{p}$-value \\
\hline range & $24-249$ & $36-156$ & 0.190 & 0.851 \\
\hline Mean \pm SD & $89.00 \pm 60.48$ & $85.47 \pm 39.03$ & & \\
\hline
\end{tabular}

Table (3) shows the comparison between Naive and experienced patients as regards their mean \pm standard deviation for AST. It shows that level of AST ranged 24 - 249 for Naïve with mean \pm SD equal to 89.00 \pm 60.48 
while the level for experienced ones ranged from 36 - 156 with mean \pm standard deviation equal to 85.47 \pm 39.03 .

The difference between both groups was not significant statistically $(\mathrm{p}=0.851)$

Fig (5): Bar chart for Mean \pm SD of AST of the studied groups

Table5:-Comparison between Naive andexperienced treatmentpatients as regard total serum bilirubin.

\begin{tabular}{|l|l|l|l|l|}
\hline \multirow{2}{*}{ Variable } & \multicolumn{2}{|l|}{ Total serum bilirubin } & \multicolumn{2}{l|}{ Significance test } \\
\cline { 2 - 5 } & $\begin{array}{l}\text { Naive patients } \\
(\mathbf{n}=\mathbf{1 5})\end{array}$ & $\begin{array}{l}\text { Experienced patients } \\
(\mathbf{n = 1 5})\end{array}$ & t-test & p-value \\
\hline range & $0.86-2.6$ & $0.6-3.3$ & 0.612 & 0.545 \\
\hline Mean \pm SD & $1.462 \pm 0.468$ & $1.309 \pm 0.845$ & & \\
\hline
\end{tabular}

Fig (6): Bar chart for Mean \pm SD of total bilirubin of the studied groups

Table5:-Comparison between Naive andexperienced treatmentpatients as regard serum albumen

\begin{tabular}{|l|l|l|l|l|}
\hline \multirow{2}{*}{ Variable } & \multicolumn{2}{|l|}{ Serum albumen } & \multicolumn{2}{l|}{ Significance test } \\
\cline { 2 - 5 } & $\begin{array}{l}\text { Naive patients } \\
(\mathbf{n = 1 5})\end{array}$ & $\begin{array}{l}\text { Experienced patients } \\
(\mathbf{n = 1 5})\end{array}$ & t-test & p-value \\
\hline range & $3.2-4.6$ & $2.5-4.4$ & 0.629 & 0.535 \\
\hline Mean \pm SD & $3.7134 \pm 0.346$ & $3.613 \pm 0.497$ & & \\
\hline
\end{tabular}

Fig (7): Bar chart for Mean \pm SD of serum albumen of the studied groups

Table6:-Comparison between Naive andexperienced treatmentpatients as regard PC.

\begin{tabular}{|l|l|l|l|l|}
\hline \multirow{2}{*}{ Variable } & PC & \multicolumn{2}{l|}{ significance-test } \\
\cline { 2 - 5 } & $\begin{array}{l}\text { Naive patients } \\
(\mathbf{n}=\mathbf{1 5})\end{array}$ & $\begin{array}{l}\text { Experienced patients } \\
(\mathbf{n = 1 5})\end{array}$ & t-test & p-value \\
\hline range & $56-88$ & $55-100$ & 1.935 & 0.063 \\
\hline Mean \pm SD & $73.667 \pm 9.049$ & $81.667 \pm 13.211$ & & \\
\hline
\end{tabular}

Fig (8): Bar chart for Mean \pm SD of PC of the studied groups

Table7:-Comparison between Naive andexperienced treatmentpatients as regard INR.

\begin{tabular}{|l|l|l|l|l|}
\hline \multirow{2}{*}{ Variable } & INR & \multicolumn{2}{l|}{ significance-test } \\
\cline { 2 - 5 } & $\begin{array}{l}\text { Naive patients } \\
(\mathbf{n = 1 5})\end{array}$ & $\begin{array}{l}\text { Experienced patients } \\
(\mathbf{n = 1 5})\end{array}$ & t-test & p-value \\
\hline range & $1-1.4$ & $1-1.98$ & 0.235 & 0.816 \\
\hline Mean \pm SD & $1.173 \pm 0.132$ & $1.190 \pm 0.241$ & & \\
\hline
\end{tabular}

Fig (8): Bar chart for Mean \pm SD of PC of the studied groups

Table8:-Comparison between Naive andexperienced treatmentpatients as regard serum creatinine.

\begin{tabular}{|c|c|c|c|c|}
\hline \multirow[b]{2}{*}{ Variable } & \multicolumn{2}{|c|}{ Serum creatinine } & \multicolumn{2}{|c|}{ significance-test } \\
\hline & $\begin{array}{l}\text { Naive patients } \\
(n=15)\end{array}$ & $\begin{array}{l}\text { Experienced patients } \\
(\mathrm{n}=15)\end{array}$ & t-test & p-value \\
\hline range & $0.58-1.2$ & $0.7-0.9$ & \multirow[t]{2}{*}{1.866} & \multirow[t]{2}{*}{0.073} \\
\hline Mean \pm SD & $.892 \pm 0.194$ & $0.791 \pm 0.080$ & & \\
\hline
\end{tabular}

Fig (9): Bar chart for Mean \pm SD of serum creatinine of the studied groups

Table9:-Comparison between Naive andexperienced treatmentpatients as regard FBG.

\begin{tabular}{|c|c|c|c|c|}
\hline \multirow[b]{2}{*}{ Variable } & \multicolumn{2}{|l|}{ FBG } & \multicolumn{2}{|c|}{ significance-test } \\
\hline & $\begin{array}{l}\text { Naive patients } \\
(n=15)\end{array}$ & $\begin{array}{l}\text { Experienced patients } \\
(\mathrm{n}=15)\end{array}$ & t-test & p-value \\
\hline range & $70-143$ & $77-110$ & 1.063 & 0.297 \\
\hline Mean \pm SD & $101.333 \pm 20.272$ & $95.20 \pm 9.405$ & & \\
\hline
\end{tabular}


Fig (10): Bar chart for Mean \pm SD of FBG of the studied groups

Table10:-Comparison between Naive and experienced treatmentpatients as regard HB.

\begin{tabular}{|l|l|l|l|l|}
\hline \multirow{2}{*}{ Variable } & \multicolumn{2}{|l|}{ ALT } & \multicolumn{2}{l|}{ significance-test } \\
\cline { 2 - 5 } & $\begin{array}{l}\text { Naive patients } \\
(\mathrm{n}=15)\end{array}$ & $\begin{array}{l}\text { Experienced patients } \\
(\mathrm{n}=15)\end{array}$ & t-test & $\mathrm{p}$-value \\
\hline range & $11.6-16.2$ & $10.5-16.0$ & 0.233 & 0.817 \\
\hline Mean \pm SD & $13.413 \pm 1.295$ & $13.280 \pm 1.797$ & & \\
\hline
\end{tabular}

Fig (11): Bar chart for Mean \pm SD of $\mathrm{HB}$ of the studied groups

Table11:-Comparison between Naive andexperienced treatmentpatients as regard WBCs.

\begin{tabular}{|l|l|l|l|l|}
\hline \multirow{2}{*}{ Variable } & WBCs & \multicolumn{2}{l|}{ significance-test } \\
\cline { 2 - 5 } & $\begin{array}{l}\text { Naive patients } \\
(\mathbf{n}=\mathbf{1 5})\end{array}$ & $\begin{array}{l}\text { Experienced patients } \\
(\mathbf{n = 1 5})\end{array}$ & t-test & p-value \\
\hline range & $3200-12000$ & $2700-9400$ & 0.607 & 0.549 \\
\hline Mean \pm SD & $5493.333 \pm 2185.1664$ & $5020.000 \pm 2048.3644$ & & \\
\hline
\end{tabular}

Table12:-Comparison between Naive andexperienced treatmentpatients as regard Platelets.

\begin{tabular}{|l|l|l|l|l|}
\hline \multirow{2}{*}{ Variable } & Platelets & \multicolumn{2}{l|}{ significance-test } \\
\cline { 2 - 5 } & $\begin{array}{l}\text { Naive patients } \\
(\mathbf{n}=\mathbf{1 5})\end{array}$ & $\begin{array}{l}\text { Experienced patients } \\
(\mathbf{n}=\mathbf{1 5})\end{array}$ & t-test & p-value \\
\hline range & $69000-178000$ & $45000-143000$ & 0.797 & 0.432 \\
\hline Mean \pm SD & $104133.3 \pm 32171.120$ & $94466.67 \pm 34269.659$ & & \\
\hline
\end{tabular}

Table13:-Comparison between Naive andexperienced treatmentpatients as regard TSH

\begin{tabular}{|c|c|c|c|c|}
\hline \multirow[b]{2}{*}{ Variable } & \multicolumn{2}{|l|}{ TSH } & \multicolumn{2}{|l|}{ significance-test } \\
\hline & $\begin{array}{l}\text { Naive patients } \\
(n=15)\end{array}$ & $\begin{array}{l}\text { Experienced patients } \\
(\mathrm{n}=15)\end{array}$ & $\begin{array}{l}\text { Mann-Whitney U } \\
\text { test }\end{array}$ & p-value \\
\hline range & $0.08-12.00$ & $0.69-5.60$ & $Z=-0.291$ & 0.771 \\
\hline Median & 1.790 & 1.800 & & \\
\hline
\end{tabular}

Table14:-Comparison between Naive and experienced treatmentpatients as regard PCR before treatment

\begin{tabular}{|c|c|c|c|c|}
\hline \multirow[b]{2}{*}{ Variable } & \multicolumn{2}{|c|}{ PCR before treatment } & \multicolumn{2}{|l|}{ significance-test } \\
\hline & $\begin{array}{l}\text { Naive patients } \\
(n=15)\end{array}$ & $\begin{array}{l}\text { Experienced patients } \\
(n=15)\end{array}$ & $\begin{array}{l}\text { Mann-Whitney U } \\
\text { test }\end{array}$ & p-value \\
\hline range & $2200-1365923$ & $12700-2600000$ & $Z=-0.643$ & 0.520 \\
\hline Median & 200000 & 267904 & & \\
\hline
\end{tabular}

Table15:-Comparison between Naive andexperienced treatmentpatients as regard PCR after treatment.

\begin{tabular}{|l|l|l|l|l|}
\hline & \multicolumn{2}{|l|}{ PCR after treatment } & significance-test \\
\cline { 2 - 5 } Variable & $\begin{array}{l}\text { Naive patients } \\
(\mathbf{n = 1 5})\end{array}$ & $\begin{array}{l}\text { Experienced patients } \\
(\mathbf{n = 1 5})\end{array}$ & $\begin{array}{l}\text { Mann-Whitney U } \\
\text { test }\end{array}$ & p-value \\
\hline range & $0.0000-900000$ & $0.0000-253000$ & $\mathrm{Z}=-0.600$ & 0.548 \\
\hline mean \pm SD & $146333.3 \pm 298282$ & $70433.33 \pm 99263.87$ & & \\
Median & 0.00000 & 0.0000 & & \\
\hline
\end{tabular}

\section{Discussion:-}

In this study, 24 weeks of treatment with sofosbuvir and RBV resulted in high rates of SVR12 in treatment-naive more than previously treated patients with genotype $4 \mathrm{HCV}$. SVR12 rates were high in patients with characteristics historically associated with poor response-cirrhosis, high baseline viral load, non-CC IL28B genotype, and prior non-response to $\mathrm{HCV}$ treatment. The regimen was well tolerated, with mostly mild adverse events typically associated with RBV therapy. Overall, RBV dose modification or interruption did not appear to have an effect on SVR. No viable resistance-associated variants were detected in any of the patients who did not achieve SVR. 
The results in our 24-week study compared favorably with other recently approved regimens for which data are currently available in patients with genotype $4 \mathrm{HCV}$. In a phase 3 trial, the second generation HCV NS3/4A protease inhibitor simeprevir was administered for 12 weeks with PegIFNa and RBV followed by a further 12-36 weeks of PegIFNa and RBV (depending on on-treatment response) to 107 patients with genotype $4 \mathrm{HCV}$. The overall rate of SVR12 was $65 \%$, but the rate varied greatly by treatment history: $83 \%$ in treatment-naive patients, $86 \%$ in prior relapsers, $60 \%$ in prior partial responders, but only $40 \%$ in patients with prior non-response (mareno et al 2014)

Other direct-acting antiviral agents have also been evaluated in phase 2 studies in patients with genotype $4 \mathrm{HCV}$ infection. One such study evaluated 12 weeks of treatment with the protease inhibitor ABT-450 with ritonavir (ABT-450/r) and the NS5A inhibitor ombitasvir, with or without RBV, in genotype 4 patients without cirrhosis (Hezode C et al 2014). In treatment-naive patients, the RBV-containing regimen resulted in a $100 \%$ SVR12 rate (n $=42 / 42)$, while the regimen without RBV resulted in a 91\% SVR12 rate $(\mathrm{n}=40 / 44)$. The SVR12 rate has not yet been reported for the group of treatment-experienced patients $(n=49)$ who received ABT-450/r plus ombitasvir plus RBV. In a small study, a total of 21 treatment-naive genotype 4 patients were randomized to receive daclatasvir, a NS5A inhibitor, and asunaprevir, a NS3 protease inhibitor, and one of two dose levels of BMS-791325, a nonnucleoside NS5B polymerase inhibitor, for 12 weeks (Hassanein T et al 2014). All 21 patients achieved SVR12, suggesting the combination of these agents merits further evaluation. The safety and efficacy of sofosbuvir in combination with the NS5A inhibitor ledipasvir in patients with genotype 4 is being evaluated in studies in Egypt and France. There is a need in Egypt for an interferon-free regimen that is well tolerated and provides a high degree of efficacy for the treatment of genotype $4 \mathrm{HCV}$ infection. However, the results from this study may have broader application. Although some studies have found response rates with interferon plus RBV to be higher in Egyptian patients than European patients with genotype 4 HCV infection (Roulot D et al 2007, Moucari R et al 2009), other studies have not found a difference in response based on ethnicity (Elefsiniotis I et al 2010, Papastergiou V et al 2012). Differences in efficacy have been associated with differences in patient characteristics including genotype 4a, which predominates in Egypt whereas in Europe genotypes 4a and 4d are common and greater subtype diversity is present in patients from Africa (Elefsiniotis I et al 2010, Antaki $\mathbf{N}$ et al 2010). The IL28B CC genotype has been associated with higher response rates to treatment with interferon plus RBV in genotype $4 \mathrm{HCV}$ infection (Asselah et al 2012) and, in turn, a higher frequency of the $C$ allele was found in Egyptian patients relative to Europeans and Sub-Saharan Africans (Asselah et al 2012). Effective interferon-free regimens are associated with important advantages in treating chronic $\mathrm{HCV}$, including sparing patients the rigors and toxicity of protracted interferon therapy. The increasing availability of such regimens has spurred calls for stepped up screening for HCV in countries of high endemicity(Asselah T, et al 2014). The findings from the present study suggest that sofosbuvir plus RBV may offer an efficacious and well tolerated treatment in patients with HCV genotype 4 infection, and one that may facilitate treatment of large numbers of Egyptian patients

\section{Conclusions:-}

The findings from the present study suggest that 24 weeks of sofosbuvir plus ribavirin is an efficacious and well tolerated treatment in patients with HCV genotype 4 infection. The interferon-free regimens are associated with important advantages in treating chronic $\mathrm{HCV}$, including sparing patients the rigors and toxicity of protracted interferon therapy.

\section{References:-}

1. Khattab MA, Ferenci P, Hadziyannis SJ, Colombo M, Manns MP, AlmasioPL,et al. Management of hepatitis C virus genotype 4: recommendations of aninternational expert panel. J Hepatol 2011; 54:1250-1262.

2. Wantuck JM, Ahmed A, Nguyen MH. Review article: the epidemiology and therapy of chronic hepatitis C genotypes 4, 5 and 6. Aliment PharmacolTher 2014; 39:137-147.

3. Ray SC, Arthur RR, Carella A, Bukh J, Thomas DL. Genetic epidemiology of hepatitis C virus throughout Egypt. J Infect Dis 2000; 182:698-707.

4. Guerra J, Garenne M, Mohamed MK, Fontanet A. HCV burden of infection in Egypt: results from a nationwide survey. J Viral Hepat 2012; 19:560-567.

5. Frank C, Mohamed MK, Strickland GT, Lavanchy D, Arthur RR, Magder LS, et al. The role of parenteral antischistosomal therapy in the spread of hepatitis C virus in Egypt. Lancet 2000; 355:887-891.

6. Rao MR, Naficy AB, Darwish MA, Darwish NM, Schisterman E, Clemens JD, et al. Further evidence for association of hepatitis C infection with parenteral schistosomiasis treatment in Egypt. BMC Infect Dis 2002; 2:29, [epub]. 
7. Esmat G, El Raziky M, El Kassas M, Hassany M, Gamil ME. Treatment of chronic HCV genotype 4 infection. CurrHepat Rep 2012; 11:250-255.

8. Muir AJ. The rapid evolution of treatment strategies for hepatitis C. Am J Gastroenterol 2014; 109:628-635.

9. Lawitz E, Mangia A, Wyles D, Rodriguez-Torres M, Hassanein T, Gordon SC, et al. Sofosbuvir for previously untreated chronic hepatitis C infection. N Engl J Med 2013; 368:1878-1887.

10. Jacobson IM, Gordon SC, Kowdley KV, Yoshida EM, Rodriguez-Torres M, Sulkowski MS, et al. Sofosbuvir for hepatitis C genotype 2 or 3 in patients without treatment options. N Engl J Med 2013; 368:1867-1877.

11. American Association for the Study of Liver Diseases and the Infectious Diseases Society of America. Recommendations for testing, managing, and treating hepatitis C. <http://www.hcvguidelines.org/>; 2014 [accessed 2.06.14].

12. EASL Clinical Practice Guidelines: management of hepatitis C virus infection. J Hepatol 2014; 60:392-420.

13. World Health Organization. Guidelines for screening, care and treatment of persons with hepatitis C infection. <http://www.who.int/hiv/pub/hepatitis/ hepatitis-c-guidelines/en/>; 2014. [Published April 2014, accessed June 2, 2014].

14. Kirby B, Gordi T, Symonds WT, Kearney BP, Mathias A. Population pharmacokinetics of sofosbuvir and its major metabolite (GS-331007) in healthy and HCV-infected adult subjects. Hepatology 2013; 58:746A.

15. Moreno C, Hezode C, Marcellin P, Bourgeois S, Francque S, and Samuel D, et al. Once-daily simeprevir (TMC435) with peginterferon/ribavirin in treatment-naive or treatment-experienced chronic HCV genotype 4infected patients: SVR12 results of a phase III trial. J Hepatol 2014; 60:S535.

16. Hezode C, Marcellin P, Pol S, Hassanein T, Fleischer-Stepniewska K, Baykal T, et al. Results from the phase 2 PEARL-I study: Interferon-free regimens of ABT-450/R + ABT-267 with or without ribavirin in patients with HCV genotype 4 infection. J Hepatol 2014; 60:S24.

17. Hassanein T, Sims K, Bennett M, Gitlin N, Lawitz E, Nguyen T, et al. All-oral therapy with daclatasvir in combination with asunaprevir and BMS-791325 for treatment-naive patients with chronic HCV genotype 4 infection. J Hepatol 2014; 60:S472.

18. Roulot D, Bourcier V, Grando V, Deny P, Baazia Y, Fontaine H, et al. Epidemiological characteristics and response to peginterferon plus ribavirin treatment of hepatitis C virus genotype 4 infection. J Viral Hepat 2007; 14:460-467.

19. Moucari R, Ripualt M-P, Martinot-Peignoux M, Voitot H, Cardoso AC, Stern C, et al. Insulin resistance and geographical origin: major predictors of liver fibrosis and response to peginterferon and ribavirin in HCV-4. Gut 2009; 58:1662-1669.

20. Elefsiniotis I, Pavlidis C, Xinopoulos D, Tsamakidis K, Patsavela S, et al. European vs. Egyptian HCV-4 patients with elevated baseline HCV RNA, treated with PEG-IFN-a2a and ribavirin: the role of rapid and early virologic response. Hepat Mon 2010; 10:193-198.

21. Papastergiou V, Dimitroulopoulos D, Skorda L, Lisgos P, Ketikoglou I, and Kostas N, et al. Predictors of sustained virological response in Greek and Egyptian patients with hepatitis C genotype 4: does ethnicity matter? J Med Virol 2012; 84:1217-1223.

22. Antaki N, Craxi A, Kamal S, Moucari R, Van der Merwe S, Haffar S, et al. The neglected hepatitis C virus genotypes 4, 5 and 6: an international consensus report. Liver Int 2010:30342-30355.

23. Asselah T, De Muynck S, Broët P, Masliah-Planchon J, Blanluet M, Bièche I, et al. IL28B polymorphism is associated with treatment response in patients with genotype 4 chronic hepatitis C. J Hepatol 2012;56:527-532.

24. Asselah T, Perumalswami PV, Dieterich D. Is screening baby boomers for HCV enough? A call to screen for hepatitis $C$ virus in persons from countries of high endemicity. Liver Int 2014; 34:1447-1451. 